\section{International Scientific Journal Theoretical \& Applied Science}

p-ISSN: 2308-4944 (print) e-ISSN: 2409-0085 (online)

Year: $2014 \quad$ Issue: $10 \quad$ Volume: 18

Published: $30.10 .2014 \quad$ http://www.T-Science.org
Elena Vladimirovna Denisova candidate of geographical Sciences, associate Professor of the Department of «Land management and land cadastre»» Volgograd state agricultural University, Russia denisov.00@mail.ru

SECTION 35. Immovable property. Land relations.

\title{
FEATURES OF USE OF AGRICULTURAL LAND UNDER INTENSIVE LAND USE
}

Abstract: : The problem of the modern use of agricultural lands is the organization of such use, which would not violate the boundaries of existing land uses, and was not created inconvenience, leading to their retirement from active circulation. Timely identify the factors that hinder the full use of agricultural land, will allow land owners to avoid additional expenses.

Key words: land, common land use, protected areas, use of agricultural land.

Language: Russian

Citation: Denisova EV (2014) FEATURES OF USE OF AGRICULTURAL LAND UNDER INTENSIVE LAND USE. ISJ Theoretical \& Applied Science 10 (18): 21-24. doi:

http://dx.doi.org/10.15863/TAS.2014.10.18.5

\section{ОСОБЕННОСТИ ИСПОЛЬЗОВАНИЯ ЗЕМЕЛЬ СЕЛЬСКОХОЗЯЙСТВЕННОГО НАЗНАЧЕНИЯ ПРИ ИНТЕНСИВНОМ ЗЕМЛЕПОЛЬЗОВАНИИ}

Аннотация: Проблемой современного использования земель сельскохозяйственного назначения является организация такого использования, при котором бы не нарушались границы существующих землепользований, и не создавались неудобства, приводящие к выбытию их из активного оборота. Своевременное выявление причин, препятствующих полноценному использованию сельскохозяйственных угодий, позволит собственникам земли избежать дополнительных материальных затрат.

Ключевые слова: земельный участок, единое землепользование, охранные зоны, использование сельскохозяйственных угодий.

В Российской Федерации в 1990-1991 годах в системе земельных отношений были начаты земельные преобразования, в результате которых произошли радикальные изменения, коренным образом изменившие социальную структуру земельных собственников. В процессе ее трансформации значительная часть земель передана в частную собственность. В стране появилось 43 миллиона земельных собственников и землевладельцев, которым передан более 130 миллионов га земли.

Однако, с возникновением частной собственности на землю, возникают и проблемы, связанные с ее использованием.

Целью данного исследования является выявление несоответствий в использовании особо ценной категории земель и разработка комплекса мероприятий, направленных на предотвращение их выбытия из оборота нерационального использования.
Земельный участок может состоять из нескольких отдельных обособленных контуров (частей), разделенных между собой.

В земельном законодательстве отсутствует определение единого землепользования. Это понятие возникло в результате внедрения новой технологии государственного кадастрового учета земельных участков.

В ряде документов Росземкадастра (Роснедвижимости) даны косвенные понятия единого землепользования. В постановлении Правительства РФ «О кадастровом делении» и в приказе Росземкадастра сказано, что несколько обособленных земельных участков, занятых или предназначенных для обслуживания входящих в один объект элементов, по желанию правообладателя можно ставить на государственный кадастровый учет в качестве одного объекта недвижимости - единого землепользования с присвоением одного кадастрового номера. 
Таким образом, можно сделать вывод о том, что единое землепользование - это составной земельный участок, каждый из его контуров считается земельным участком и числится в ГКН под своим кадастровым номером. При этом такие участки не являются самостоятельными объектами гражданских отношений, т. е. не могут быть предметами сделки по отдельности друг от друга. Само единое землепользование имеет свой кадастровый номер и является самостоятельным объектом гражданских отношений.

После вступления в силу Федерального закона от 24.07.2007 г. № 221-Ф3 "О государственном кадастре недвижимости" - с 1 марта 2008 года для учета участков, состоящих из 2-х и более частей, было введено понятие многоконтурный земельный участок.

Многоконтурный земельный участок - это земельный участок, контур границы которого состоит из 2-х и более замкнутых контуров.

Бывает два типа многоконтурных участков:

- несколько разделенных между собою контуров;

- земельные участки с вкраплениями.
Основным различием между единым землепользованием и многоконтурным участком является то, что каждому обособленному участку единого землепользования присваивался кадастровый номер, а каждой части многоконтурного земельного участка - не присваивается, кадастровый номер имеет только сам многоконтурный земельный участок [2].

На практике, использование такого земельного участка влечет за собой и определенные трудности.

Единое землепользование, расположенное на территории Гончаровского сельского поселения Палассовского района Волгоградской области, является таким примером. Данный земельный участок предоставлен для целей производства сельскохозяйственной продукции, общей площадью 1020,0 га в который входят два обособленных участка с кадастровыми номерами: 1 - 34:23:090005:250 площадью $4520000 \mathrm{~m}^{2}, 2$ - 34:23:090005:251 площадью $5680000 \mathrm{~m}^{2}$ (рис. 1$)$.

В результате проведения земельнокадастровых работ было выявлено, что через единое землепользование проходит граница ЛЭП с установленной охранной зоной.
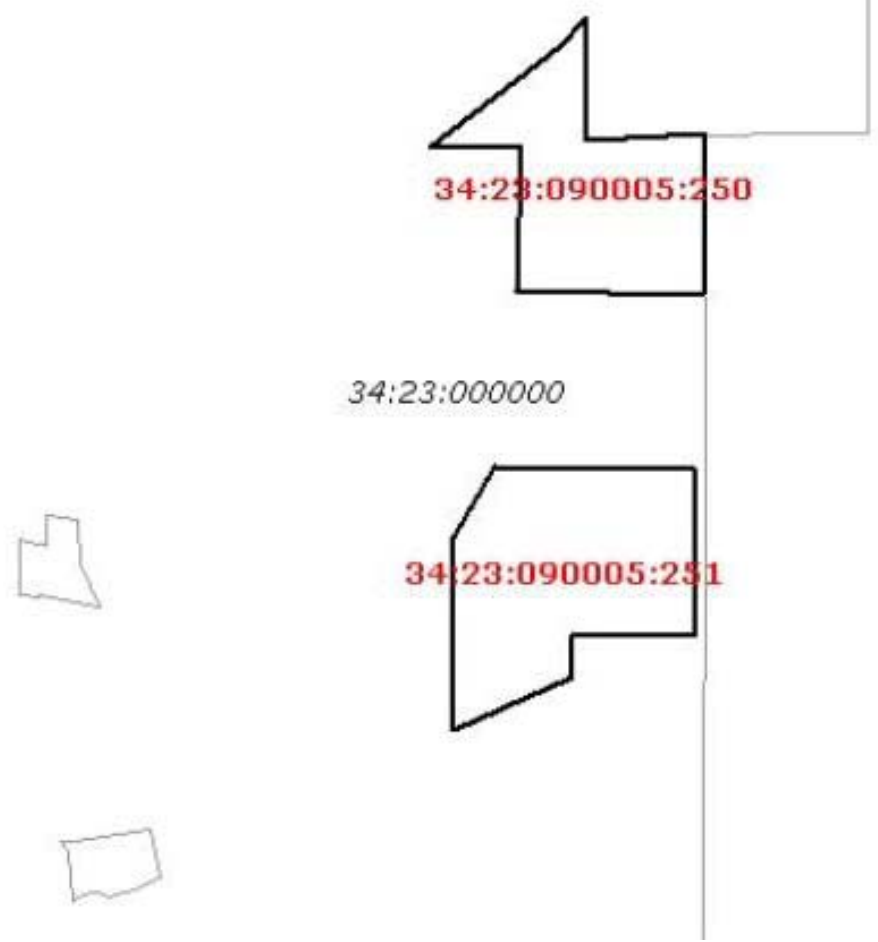

Рисунок 1 - Расположение земельных участков на кадастровом плане.

Согласно постановлению Правительства РФ «О порядке установления охранных зон объектов электросетевого хозяйства и особых условий использования земельных участков, 
расположенных в границах таких зон» в охранных зонах запрещается осуществлять любые действия, которые могут нарушить безопасную работу объектов электросетевого хозяйства, в том числе привести к их повреждению или уничтожению, и (или) повлечь причинение вреда жизни, здоровью граждан, и имуществу физических или юридических лиц, а также повлечь нанесение экологического ущерба и возникновение пожаров, в том числе:

а) набрасывать на провода и опоры воздушных линий электропередачи посторонние предметы, а также подниматься на опоры воздушных линий электропередачи;

б) размещать любые объекты и предметы (материалы) в пределах, созданных в соответствии с требованиями нормативнотехнических документов проходов и подъездов для доступа к объектам электросетевого хозяйства, а также проводить любые работы и возводить сооружения, которые могут препятствовать доступу к объектам электросетевого хозяйства, без создания необходимых для такого доступа проходов и подъездов;

в) находиться в пределах огороженной территории и помещениях распределительных устройств и подстанций, открывать двери и люки распределительных устройств и подстанций, производить переключения и подключения в электрических сетях (указанное требование не распространяется на работников, занятых выполнением разрешенных в установленном

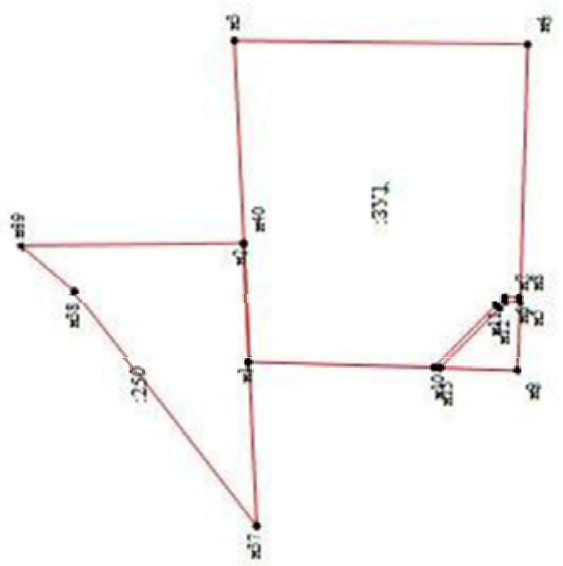

порядке работ), разводить огонь в пределах охранных зон вводных и распределительных устройств, подстанций, воздушных линий электропередачи, а также в охранных зонах кабельных линий электропередач;

г) размещать свалки;

д) производить работы ударными механизмами, сбрасывать тяжести массой свыше 5 тонн, производить сброс и слив едких и коррозионных веществ и горюче-смазочных материалов (в охранных зонах подземных кабельных линий электропередачи).

В охранных зонах, установленных для объектов электросетевого хозяйства напряжением до 1000 вольт, без письменного решения о согласовании сетевых организаций запрещается:

a) размещать детские и спортивные площадки, стадионы, рынки, торговые точки, полевые станы, загоны для скота, гаражи и стоянки всех видов машин и механизмов (в охранных зонах воздушных линий электропередачи);

б) складировать или размешать хранилища любых, в том числе горюче-смазочных, материалов;

в) устраивать причалы для стоянки судов, барж и плавучих кранов, бросать якоря с судов и осуществлять их проход с отданными якорями, цепями, лотами, волокушами и тралами (в охранных зонах подводных кабельных линий электропередачи) [5].

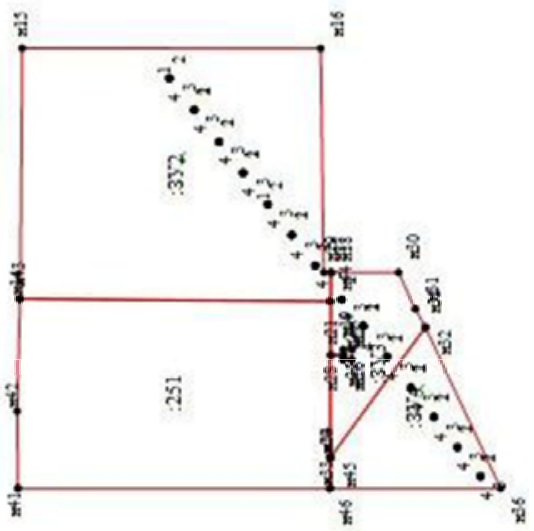

Рисунок 2 - Чертеж земельных участков и их частей.

Доступ к объектам электросетевого хозяйства для их эксплуатации и плановых (регламентных) работ осуществляется в соответствии с гражданским и земельным законодательством. Для предотвращения или устранения аварий работникам сетевых организаций обеспечивается беспрепятственный доступ к объектам электросетевого хозяйства, а также возможность доставки необходимых материалов и техники.

Охранные зоны устанавливаются вдоль воздушных линий электропередачи в виде части поверхности участка земли и воздушного пространства (на высоту, соответствующую высоте опор воздушных линий электропередачи), ограниченной параллельными 
вертикальными плоскостями, отстоящими по обе стороны линии электропередачи от крайних проводов при не отклоненном их положении при проектным номинальным классом напряжения 110 кВ на расстоянии 25 м.

Проведение земельно-кадастровых работ было обусловлено производственной необходимостью, так как фактическое полноценное использование земельных участков затруднено наличием вышеперечисленных сооружений.

Кроме того, проходящая линия ЛЭП вызывает раздробленность земельного массива на несколько земельных участков. Также существуют технологические трудности при работе техники при ведении сельскохозяйственных процессов.

Необходимо отметить, что проведение такого вида работ осуществлялось за счет собственника земельного участка, что принесло ему дополнительные материальные потери.
В связи с этим, при возникновении подобных ситуаций в использовании земельных участков сельскохозяйственного назначения, были сделаны следующие выводы:

1. Использование земель сельскохозяйственного назначения должно быть рациональным и с учетом природоохранных требований.

2. При возникновении трудностей в использовании земельных участков, связанных с прохождением линейных объектов, необходимо изыскивать резервы для их обмена на равноценные земельные участки.

3. Своевременное проведение инвентаризационных работ в границах сельских поселений, позволит сформировать резервные фонды для таких случаев.

4. Работы, связанные с установлением охранных зон в границах сельскохозяйственных угодий, принадлежащих гражданам на правах собственности, необходимо проводить на счет муниципальных средств.

\section{References:}

1. (2001) Land Code of the Russian Federation of October 25, 2001 No. 136-FZ (as amended., On 21.07.2014, the) [Text] Consultant Plus. - Mode of access:

http://www/consultant.ru/popular/earth/

2. (2007) The Federal Law of July 24, 2007 No. 221-FZ "On State Cadastre of Real Estate" (with rev., On 21.07.2014, the) [electronic resource] Consultant Plus. - Mode of access: http://www/consultant.ru/popular/earth/

3. (2010) Federal Law of the Russian Federation of December 29, 2010 No. 435-FZ "On Amendments to Certain Legislative Acts of the Russian Federation with regard to improvement of agricultural lands" [electronic resource] Consultant Plus. - Mode of access: http://www/consultant.ru/popular/earth/

4. (2006) On State Land Supervision [electronic resource]: Resolution of the Government of the Russian Federation of November 15, 2006 No. 689 (amended., From 05.06.2013g.) Consultant Plus. - Mode of access: http://www/consultant.ru/popular/earth/

5. (2009) On the order of establishment of security zones of transmission facilities and special conditions of use of land located within the boundaries of these zones [electronic resource]: Resolution of the Government of the Russian Federation of February 24, 2009 No. 160 (eds. From 26.08.2013 y) Consultant plus. - Mode of access: http://www/consultant.ru/popular/earth/

6. (1994) On additional measures for the implementation of land reform in the region [electronic resource]: the decision of the Head of the Administration of Volgograd from 08.02.1994, No. 61 (eds. From 12.03.2013 No. 165) Official site of the Volgograd region. Mode of access: http://www.volgolaws.ru/

7. Denisova EV (2013) More efficient use of agricultural land during the cadastre works. International Research Journal: Collected by the results of the scientific conference XIX Research Journal of International Studies. Ekaterinburg: MNIZH - 2013. - No. 9 Part 3, pp. 55-57.

8. (2011) Guidelines to improve the circulation and use of agricultural land. - Moscow: FGBNU "Rosinformagroteh", 128.

9. (2004) Summary of materials for monitoring land Goncharovskiy rural settlement Palassovskogo region Volgograd region. Office of the Federal Real Estate Cadastre Agency for the Volgograd region. - Volgograd, pp.1-40. 